\title{
INDEMNIZACIÓN POR ERROR JUDICIAL EN LA PERSPECTIVA DEL NUEVO PROCEDIMIENTO PENAL
}

\author{
Miguel Angel Fernández González
}

Abogado / Magister en Derecho Público

Profesor de Derecho Político y Constitucional

Universidad Católica, Universidad de Chile y Universidad de los Andes

\section{INTRODUCCIÓN}

El artículo $19^{\circ} \mathrm{N}^{\circ} 7^{\circ}$ asegura a todas las personas la libertad personal y seguridad individual, incluyéndose, en su letra i), el derecho a reclamar una indemnización del Estado cuando el afectado haya sido objeto de un error judicial en causa criminal ${ }^{1}$

Util resulta indagar en torno del sentido y alcance de esta disposición constitucional, especialmente, teniendo a la vista el Nuevo Código de Procedimiento Penal, contenido en la Ley $N^{\circ} 19.696$, publicada en el Diario Oficial el 12 de octubre de 2000.

\section{ANTECEDENTES}

La Constitución de 1925 ya contemplaba, en su artículo 20², la indemnización por error judicial en causa criminal, pero fue un precepto sin aplicación en la práctica, pues, como se explicaba por la Comisión de Estudio de la Nueva Constitución:

"Este precepto (el artículo $20^{\circ}$ de la Constitución de 1925) sólo constituyó una disposición programática, ya que por no haberse dictado a ley, no pudo ser realidad este derecho.

Esta situación de injusticia en que se han encontrado hasta ahora las personas que han sido víctimas de una privación de libertad siendo en definitiva inocentes, se

\footnotetext{
${ }^{1}$ Dispone la norma citada que:

" Una vez dictado sobreseimiento definitivo o sentencia absolutoria, el que hubiere sido sometido a proceso o condenado en cualquier instancia por resolución que la Corte Suprema declare injustificadamente errónea o arbitraria, tendrá derecho a ser indemnizado por el Estado de los perjuicios patrimoniales y morales que haya sufrido. La indemnización será determinada judicialmente en procedimiento breve y sumario y en él la prueba se apreciará en conciencia "

2 "Todo individuo en favor de quien se dictare sentencia absolutoria o se sobreseyere definitivamente, tendrá derecho a indemnización, en la forma que determine la ley, por los perjuicios efectivos o meramente morales que hubiere sufrido injustamente".
} 
repara en el Anteproyecto mediante una normativa que se basta a sí misma y que no requiere de la dictación de una ley complementaria.

Se ha estimado necesario requerir el pronunciamiento de la Corte Suprema en los términos expuestos como elemento previo a la procedencia de la indemnización, ya que la Comisión estimó, que conceder ésta en términos irrestrictos podría generar un costo excesivo e injustificado para el erario nacional, y un factor de perturbación en la libertad interior con que los tribunales deben administrar justicia.

No hay que olvidar que muchos procesos o condenas que en definitiva terminan en sentencia absolutoria o sobreseimiento definitivo en el curso posterior del juicio, pueden haber tenido fundamento plausible, a la luz de los antecedentes o ponderaciones que el tribunal realizó en el momento de dictar la resolución pertinente.

La norma propuesta ha buscado un equilibrio adecuado entre los intereses en juego, a fin de evitar que una disposición que pretende ser demasiado amplia, quede sin poder aplicarse en la práctica, como desgraciadamente ocurrió con el artículo $20^{\circ}$ de la Carta de $1925^{\prime \prime 3}$.

La situación descrita por la Comisión de Estudio, en cuanto al carácter programático que tuvo la disposición durante la vigencia de la Constitución de 1925 , fue confirmada tanto por la jurisprudencia ${ }^{4}$ como por la doctrina que se pronunció respecto del referido artículo $20^{\circ}$ :

"El profesor Guerra, en su Obra "La Constitución de 1925 " nos informa que esta disposición " fue adoptada con el mayor desgano por la Subcomisión, únicamente por complacer a la exigencia del miembro que la propuso en nombre de un partido político" 5 .

Durante la discusión de este precepto, cuya iniciativa correspondió a don Nolasco Cárdenas, el Presidente Alessandri expresó que "este es un principio doctrinario no más, que no podrá tener aplicación mientras la ley no lo consulte y la indemnización deberá pagarla la persona que ella establezca" ${ }^{6}$.

\footnotetext{
${ }^{3}$ Comisión de Estudio: Informe con Ideas Precisas, reproducido en VIII Revista Chilena de Derecho № 1 - 6 ( 1981 ) p. 198.

${ }^{4}$ Sentencia pronunciada por la Corte Suprema el 27 de octubre de 1941, reproducida en XXXIX Revista de Derecho y Jurisprudencia, 2a, p., S. 1․, p. 301.

${ }^{5}$ GUERRA José Guillermo: La Constitución de 1925 ( Santiago, Establecimientos Gráficos Balcells, 1929) p. 156.

${ }^{6}$ Actas Oficiales de las Sesiones Celebradas por la Comisión y Subcomisión encargadas del Estudio del Proyecto de la Nueva Constitución Política de la República ( Santiago, Imprenta Universitaria, 1925 ) p. 485.
} 
Mientras no se dicte la ley, el artículo $20^{\circledR}$ seguirá constituyendo una declaración programática incumplida de nuestra Constitución" ?

En consecuencia, la inutilidad de la disposición constitucional contenida en el referido artículo $20^{\circ}$, dado su carácter meramente programático, resulta radicalmente modificada a la luz del Principio de Vinculación Directa que hoy consagra la Constitución de 1980 , en su artículo $6^{\circ}$ inciso $2^{\circ}$, en virtud del cual la Carta Fundamental tiene fuerza normativa ${ }^{8}$. Así, la acción que emana del artículo $19^{\circ} \mathrm{N}^{\circ} 7^{\circ}$ letra i) goza de plena vigencia y de indudable aplicación ${ }^{9}$, lo cual no puede ser alterado, sin incurrirse en inconstitucionalidad, por acción u omisión, o en desaplicación de los principios, valores y normas fundamentales, en virtud de la configuración de un Nuevo Procedimiento Penal a nivel simplemente legal.

\section{REQUISITOS}

Al tenor de lo preceptuado en el artículo $19^{2}^{0} 7^{0}$ letra i) de la Constitución, para que proceda la indemnización por error judicial, es necesario: Que una persona haya sido sometida a proceso o condenada, en cualquier instancia, en un juicio criminal; que se haya dictado, respecto de esa persona, sobreseimiento definitivo o sentencia absolutoria; y que la Corte Suprema declare injustificadamente erróneo o arbitrario el sometimiento a proceso o la condena ${ }^{10}$.

En cuanto a quién debe pagar la indemnización, bajo la Constitución de 1980, no hay duda que corresponde al Estado, como lo señala expresamente el artículo $19^{\circ} \mathrm{N}^{\circ} 7^{\circ}$ letra i) de la Carta Fundamental, según quedó constancia expresa en las Actas de la Comisión de Estudio de la Nueva Constitución, sesión 117, p. 26.

7 ANDRADE GEYWITZ Carlos: Elementos de Derecho Constitucional Chileno ( Santiago, Ed, Juridica de Chile, $1963)$ ) pp. $193-194$.

${ }^{8}$ FERNÁNDEZ GONZÁLEZ Miguel Angel: "La Fuerza Normativa de la Constitución", ponencia presentada en las XXXI Jornadas de Derecho Público, realizadas en la Facultad de Derecho de la Universidad de Chile, en noviembre de 2000 (en prensa). Alli sostengo que, a partir del Principio de Fuerza Normativa o de Vinculación Directa o Inmediata de la Constitución, consagrado en su artículo artículo $6^{2}$ inciso $2^{2}$, se puede requerir, ante el Tribunal competente, la aplicación directa de cualquier disposición constitucional, para que el juez adopte las medidas tendientes a la protección y eficacia de los derechos fundamentales o para que declare la omisión, dando lugar a la indemnización de perjuicios pertinente o al control político o institucional según corresponda.

A partir del Principio referido y atendido que él se aplica también a los Tribunales, es obligación de estos preterir las normas legales o sublegales contrarias a la Constitución, por lo que, cuando la ley vulnera la Constitución, particularmente en el ámbito de los derechos fundamentales, es obligación del juez despreciar aquella norma que, entonces no es tal, y proceder a la resolución del asunto sin considerarla, porque tiene que aplicar la Carta Fundamental, quedando a salvo, ciertamente $y$ en todo caso, los derechos de las partes para impugnar aquella decisión, a través de los recursos de jerarquía constitucional o legal que procedan.

${ }^{9}$ Léase la intervención del profesor SILVA BASCUÑÁN Alejandro en las Actas de la Comisión de Estudio de la Nueva Constitución, citadas en supra nota 6 , sesión 120 , p. 8.

${ }^{10}$ MENDOZA Adelaida y TAPIA Cristián: El Error Judicial ( Memoria de Grado, Universidad Central de Santiago. 1996 ). 


\section{ERROR EN CAUSA CRIMINAL}

El primero de los requisitos aludidos exige que la causa en la cual se ha cometido el error judicial sea criminal, con lo cual nuestra Constitución sigue el sentido restringido de aquella institución:

"El error judicial es el falso concepto que tiene el juez respecto de la verdad de los hechos que son materia del proceso ${ }^{11}$.

En sentido amplio, el error judicial puede presentarse no sólo en el proceso penal, sino también en el civil y en cualquier otro proceso judicial, Comprendería, por tanto, no solamente los perjuicios producidos en el inocente, sino también los errores o faltas que afecten al culpable. Puede incluir, además, tanto el error de hecho como el error de derecho.

El error judicial, en sentido restringido, consiste en aquel cometido durante el proceso criminal como consecuencia de un procesamiento o condena injusta, en perjuicio de una persona cuya inocencia se comprueba con posterioridad, dictándose el correspondiente sobreseimiento definitivo o sentencia absolutoria" ${ }^{12}$.

La jurisprudencia que se ha pronunciado respecto del artículo $19^{\circ} \mathrm{N} N 7^{\circ}$ letra i) confirma que la acción indemnizatoria se refiere sólo al juicio criminal, tal y como ocurría bajo el imperio de la Constitución de 1925, sobre la base de la historia fidedigna del actual precepto y de su predecesor, así como de la doctrina que ha analizado el tópico:

"Que, en todo caso, resulta digno de destacarse aquí, para la mejor comprensión de la norma constitucional en actual vigencia, que la normativa del año 1925, tenía como finalidad producir sus efectos en relación con los errores judiciales producidos en la tramitación de un juicio criminal, entendiéndose la palabra "juicio", como sucede habitualmente en nuestra terminología jurídica, como sinónimo de proceso, y, más concretamente, como sinónimo del procedimiento a través del cual se desenvuelve todo un proceso.

El criterio del Constituyente del año 1925 en el sentido de limitar el derecho indemnizatorio a equivocaciones cometidas con motivo de un juicio criminal o penal surge palmario, tanto de la letra del artículo $20^{\circ}$ como de la historia de su

\footnotetext{
11 Al decir de PUIG PEÑA Federico: "El Error Judicial desde el punto de vista de las Leyes Orgánicas de la Administraciôn de Justicia " en VIII Revista de Derecho Español y Americano ( 1963 ): "El error judicial consiste en toda antinomia producida entre la verdad material y la verdad oficial, no captada por el juzgador" ( p. 5 ).

${ }^{12}$ GARCIA MENDOZA Hernán: La Responsabilidad Extracontractual del Estado (Santiago, Ed. Jurídica Conosur, 1997 ) p. 224.
} 
establecimiento (...) (decimonovena Sesión de la Subcomisión de Reformas Constitucionales, celebrada el 8 de junio de 1925);

Que, en el aspecto doctrinario también se entendió que el artículo $20^{\circ}$ de la Constitución de 1925, tenía la finalidad de permitir la indemnización de errores ocasionados con motivo de un juicio criminal. Así Alejandro Silva Bascuñán, comentando la indemnización para el absuelto o sobreseído, expresa que "la necesidad de eficacia de la acción penal y las dificultades inherentes a la investigación de los delitos, hacen que muchas personas se vean en el caso de sufrir privación de libertad y otros graves daños patrimoniales y morales consecuentes al proceso, a pesar de su completa inocencia y sin tener responsabilidad alguna en los hechos investigados". (Tratado de Derecho Constitucional, Tomo II, p.337);

Que, nuestro legislador, no permanece ajeno a estas influencias, y es así como puede fácilmente observarse que el texto expreso del artículo $19^{\circ} N^{\circ} 7^{\circ}$, i) de la Ley Fundamental vigente lleva a circunscribir su alcance, tal como según ya se ha visto en el considerando $5^{\circ}$ de este fallo ocurrió con el Constituyente de 1925, sólo al ámbito del juicio o proceso criminal (...);

Que, la conclusión a que se arriba en el fundamento anterior, derivada de la letra del precepto constitucional, se corrobora ampliamente con la lectura de las Actas de la Comisión (...). Así es como pueden observarse referencias precisas a la necesaria existencia de un " juicio criminal " en la indicación propuesta en Sesión 121 a como sustitutiva al artículo $20^{\circ}$ de la Constitución de 1925 y en las sucesivas intervenciones de todos los miembros de la Comisión en Sesión $122^{\text {a }}$ en el curso de la cual, en diversas formas, se refirieron a un juicio o proceso de esta índole penal;

Que, esta exigencia -necesidad del juicio criminal- como requisito esencial para que pueda hacerse efectiva la responsabilidad del Estado por aplicación de lo dispuesto en el artículo $19^{\circ}$ № $7^{\circ}$, letra i) de la Constitución Política, no ha pasado inadvertida para la doctrina nacional. Hugo Caldera Delgado expresa al respecto que "hay que tener presente que la responsabilidad extracontractual orgánica, de que trata el artículo $19^{\circ}^{N} 7^{\circ}$ letra i), sólo puede producir efectos reparatorios - poner en juego la obligación de indemnizar- cuando los vicios hayan recaído en un juicio criminal (...) " (Sistema de la Responsabilidad Extracontractual del Estado en la Constitución Política de 1980, Ed. Jurídica de Chile, p. 32)" 13 .

Cuanto se ha expuesto, sin embargo, no obsta a que los Tribunales, Ordinarios o Especiales, sujetos o no a la superintendencia de la Corte Suprema, puedan causar

\footnotetext{
${ }^{13}$ Considerandos $5^{\circ}, 6^{\circ}$ y $11^{\circ}$ a $13^{\circ}$ de la sentencia pronunciada el 2 de junio de 1983 , reproducida en $L X X X$ Revista de Derecho y Jurisprudencia 2 p., S. 5, pp. 11-120.
} 
daño a las personas en cualquier otra especie de causa, aunque no sea del ámbito criminal. Lo que ocurre, es que, en estos casos -es decir, en la regla general-, habrá de acudirse al régimen regular de responsabilidad del Estado y no podrá impetrarse la acción especial contemplada en el artículo $19^{\circ} \mathrm{N}^{\circ} 7^{\circ}$ letra i) de la Constitución ${ }^{14}$.

En este sentido, no puede dejar de mencionarse que el Poder Constituyente ha consagrado acciones especiales para reclamar indemnizaciones del Estado sólo cuando el causante del agravio es el Estado-Juez en causa criminal, el Estado-Administración y las Municipalidades ${ }^{15}$. Empero, cuando el autor del agravio sea el Estado-Juez en causa que no sea criminal, el Legislador, un Organo Constitucionalmente Autónomo ${ }^{16}$ o el Presidente de la República, en ejercicio de su función política, ciertamente no puede creerse que la persona perjudicada carezca del derecho a ser indemnizada. $Y$ ello encuentra su fundamento constitucional en los artículos $6^{\circ}$ y $7^{\circ}$ del Código Político, así como, primordialmente, en el Principio General de Derecho consagrado en su artículo $19^{\circ} \mathrm{N}^{\circ} 24^{\circ}$ inciso $3^{\circ}$, en virtud del cual nadie puede, en caso alguno, ser privado de lo suyo.

Por ende, el artículo $19^{\circ} \mathrm{N}^{\circ} 7^{\circ}$ letra i) crea una acción especial que no excluye ni prohíbe el ejercicio de las demás acciones indemnizatorias, establecidas en la Constitución o las que contemple el Derecho Común, para resarcirse de los perjuicios ocasionados por cualquier órgano estatal, incluyendo a los Tribunales en causa que no sea criminal

\section{SOMETIDO A PROCESO O CONDENADO}

Junto a la limitación consistente en que el error judicial se haya producido en causa criminal, el Poder Constituyente habría configurado una segunda restricción. En efecto, el error debería haberse producido con motivo de o en una resolución judicial precisa y no en cualquier acto del proceso penal. Esta afirmación, que será corroborada por la doctrina y jurisprudencia, tiene efectos inesperados $y$, dable es suponer que, no deseados en relación al Nuevo Código de Procedimiento Penal, como se explicará, por lo que debe ser cuidadosamente revisada.

\footnotetext{
${ }^{14}$ SOTO KLOSS Eduardo: " Bases para una Teoria General de la Responsabilidad Extracontractual del Estado en el Derecho Chileno " en Revista de Derecho ( Valparaíso, EDEVAL, 1985 ) pp, 331 - 347; HERNÁNDEZ EMPARANZA Domingo: “Indemnización del Error Judicial" en Revista de Derecho Público N²5 - 26, pp. 193 194; y CALDERA DELGADO Hugo: "Interpretación que la Corte Suprema ha dado a la Norma Constitucional sobre Indemnización del Error Judicial " en Gaceta Jurídica N 70, pp. 10 - 11.

${ }^{15}$ Artículos $19^{\circ} \mathrm{N}^{\circ} 7^{\circ}$ letra i ) y $38^{\circ}$ inciso $2^{\circ}$ de la Constitución

${ }^{16}$ En nexo con el Ministerio Público, téngase presente lo preceptuado en el artículo $5^{\circ}$ de su Ley Orgánica Constitucional, el cual se comenta al final de este artículo.
} 
Por ello y tratándose, al menos, de los casos a que se aplique este Nuevo Código, la normativa constitucional deberá ser objeto de una interpretación y aplicación actualizada que, a la luz de los principios y reglas que inspiran el nuevo Enjuiciamiento Criminal, haga subsistir, más allá de aquel cuerpo de jerarquía meramente legal, la Fuerza Normativa de la Carta Fundamental y su aplicación directa, especialmente cuando se trata del resguardo y protección de la honra, de la persona y de su familia, así como de la integridad patrimonial y moral de sus haberes, a través de la acción especial consagrada en el artículo $19^{\circ} \mathrm{N}^{\circ} 7^{\circ}$ letra i) de la Constitución.

\section{A. PLANTEAMIENTO TRADICIONAL}

Se ha vuelto común sostener que el error que motiva el derecho a ser indemnizado debe haberse cometido en la resolución que somete a proceso o en la que condena al afectado, por lo que, al adoptar alguna de esas resoluciones judiciales, se incurre en la equivocación grave que habilitará, de concurrir los demás requisitos previstos en la Carta Fundamental, para ejercer la acción constitucional en estudio ${ }^{17}$.

Así, para dilucidar el significado de aquellas dos resoluciones judiciales, se ha acudido a los artículos $274^{\circ}$ y $500^{\circ}$ del Antiguo Código de Procedimiento Penal, al tenor de los cuales el sometimiento a proceso es la resolución judicial, pronunciada en el proceso criminal, cuando, una vez que se ha interrogado al inculpado, el juez considera que está justificada la existencia del delito que se investiga y aparecen presunciones fundadas para estimar que el inculpado ha tenido participación en el delito como autor, cómplice o encubridor; y la condena es la sentencia definitiva, pronunciada en el proceso criminal, en virtud de la cual se resuelve que el procesado es responsable del delito que se le imputa, imponiéndosele la pena que, al efecto, se contempla para el tipo penal respectivo.

En consecuencia, la acción que se concede por el numeral $7^{\circ}$ letra i) del artículo $19^{\circ}$ de la Constitución sería doblemente restringida, puesto que correspondería impetrarla nada más que, por una parte, por la responsabilidad del Estado-Juez en causa criminal; $y$, de otra, porque sólo procedería cuando el daño causado por el Juez se haya producido en la resolución que sometió a proceso o en la que condenó, cualquiera sea la instancia en que esa resolución fue dictada.

Así lo ha decidido la jurisprudencia:

"Que, aun cuando lo que, en el presente caso, se deja dicho precedentemente sobre la validez y legitimidad del auto de reo sería -también- adecuado referirlo a la

${ }^{17}$ Actas citadas en supra nota 6, sesión 119, p. 13 
resolución que le formuló acusación en estos antecedentes al procesado Raddatz es lo cierto que este tipo de resolución no autoriza a producir el derecho que contempla la letra i) del № $7^{\circ}$ del artículo $19^{\circ}$ de la Constitución Política, el que sólo surge cuando la extralimitación injustificadamente errónea o arbitraria se concreta en un auto de procesamiento o en sentencia pronunciada en cualquiera instancia; $y$, por lo tanto, no es procedente que esta Corte Suprema formule declaración -en este fallo- sobre semejante particular, respecto de resoluciones que no son las aludidas en la norma constitucional señalada" ${ }^{18}$.

Por ende, la Corte Suprema ha considerado sinónimo del auto de procesamiento la expresión constitucional sometido a proceso, restringiendo el alcance de esta última a la resolución referida en el artículo $274^{\circ}$ del Antiguo Código de Procedimiento Penal.

\section{B. HISTORIA FIDEDIGNA EN RELACIÓN AL SOMETIDO A PROCESO}

La tesis sostenida, sin excepciones, por la Corte Suprema, así como por la mayoría de la doctrina, en cuanto a que el error injustificado o la arbitrariedad del Juez debe haberse cometido en una determinada resolución y que ésta no es otra más que el auto de procesamiento o la sentencia condenatoria, ha sido configurada, especialmente, sobre la base de la historia fidedigna del precepto, la que confirmaría el sentido estricto de la norma constitucional en esta materia.

Empero, debe destacarse que, según consta del debate habido en la Comisión de Estudio, el tópico no resultó pacífico ni claro, en lo relativo al alcance y extensión de la locución sometido a proceso. Las dudas allí planteadas, aparentemente despejadas en los mismos anales, las cuales -en realidad- sólo vinieron a ser dilucidadas, equivocadamente como se explicará, por la jurisprudencia y la doctrina con sentido restrictivo, adquieren hoy, sin embargo, relevancia a la vista del Nuevo Código de Procedimiento Penal, atendido que en éste desaparece el auto de procesamiento con el rasgo capital que poseía en el Código de $1906^{19}$, lo cual justifica una extensa y completa transcripción de esos anales:

"El señor Guzmán no cree que sea conveniente restringir la declaración de error injustificado o arbitrariedad a la resolución judicial que encarga reo a una persona.

\footnotetext{
${ }^{18}$ Considerandos $5^{\circ}, 6^{\circ}$ y $9^{\circ}$ a $13^{\circ}$ de la sentencia pronunciada el 2 de junio de 1983 , reproducida en LXXX Revista de Derecho y Jurisprudencia p., S. 5, pp. 11- 120.

${ }^{19}$ Podria pensarse que el auto de procesamiento, en el Nuevo Código de Procedimiento Penal, equivale a la prisión preventiva, regulada en el Libro I Título $\mathrm{V}$ párrafo $4^{\circ}$ de aquel Código. Sin embargo, dicha institución-semejante a la prisión preventiva prevista en el artículo $274^{\circ}$ del Antiguo Código-no se homologa, en su espiritu, alcance. finalidad e importancia, al auto de procesamiento, conforme al rol que a éste le corresponde en el Código de 1906. al tenor de su articulo $403^{\circ}$.
} 
Estima que la idea es más amplia, porque puede ocurrir que la resolución que encarga reo en sí misma no sea injustificadamente errónea o arbitraria y que con posterioridad, del curso del proceso, de su duración, de la forma en que se lleve el proceso, del hecho de que no se adopten medidas para revocar, por ejemplo, un auto encargatorio de reo que pudiera ser erróneo, pueda venir el perjuicio que se derive al sujeto. En otras palabras, lo que él cree que tiene que ser injustificadamente erróneo o arbitrario es el proceso como conjunto, no la resolución que encarga reo, específicamente considerada.

El señor Schweitzer (Ministro de Justicia) acota que eso es lo que se dijo aquí.

El señor Ortúzar (Presidente) opina que únicamente la resolución que encarga reo es la que, en el hecho, priva de libertad.

El señor Guzmán piensa que dicha resolución puede no privar de la libertad.

El señor Ortúzar (Presidente) considera que no puede privarse de la libertad sino a través de la resolución encargatoria de reo.

El señor Guzmán estima que no debe confundirse el problema de la libertad, que nada tiene que ver en esto, pues aquí se está hablando de los perjuicios que haya sufrido una persona como consecuencia de un proceso, sea que este proceso la privó de la libertad, sea que la haya privado de ella. De manera, que el problema de la libertad cree que habría que excluirlo de las consideraciones que les ocupan.

Agrega que lo que él sostiene es que el perjuicio que se debe indemnizar es el que sufra una persona como consecuencia de un proceso injusto, es decir, injustificadamente erróneo o arbitrario. Ahora, este proceso tiene siempre su origen en una resolución que encarga reo, pero no es esa resolución específica la que va a tener que calificar la Corte Suprema, sino el conjunto del proceso al que ha sido sometida la persona, porque darse el caso de que le encargatoria de reo sea razonablemente errónea, es decir, que haya habido en ese momento presunciones fundadas, pero que después los Tribunales se hayan comportado de una manera manifiestamente errónea o arbitraria y eso sí que ha perjudicado a la persona

El señor Evans (...) en seguida pregunta, ¿no podría ser la acusación injustificadamente errónea o arbitraria, es decir, la resolución por la cual el juez acusa al término del sumario? (...). Por eso, comparte con el señor Guzmán la idea de que la resolución de la Corte Suprema no debe referirse sólo al auto encargatorio de reo, sino que se deben abrir las puertas para que pueda declarar injustificadamente errónea cualquier resolución que durante el proceso criminal se haya producido en los términos que señala el precepto y cauce la privación injustificada de la libertad del afectado. 
El señor Guzmán observa que no debe tratarse necesariamente de la privación injustificada de la libertad, sino que puede existir un perjuicio patrimonial o moral, sin que éste se derive de la privación de libertad, o aún sin que ésta se haya producido.

El señor Evans concuerda con la opinión del señor Guzmán, pero cree que generalmente va a producir esto.

El señor Evans admite que la idea de que " hubiera sido sometida a proceso " debe eliminarse, porque aparece como sinónima de "encargada reo".

El señor Evans cree que puede cambiarse la expresión "sometida a proceso", que puede inducir al equívoco señalado por el señor Ministro, por "que hubiere sido sometida a juicio criminal", con lo cual el precepto quedaría en la siguiente: "Toda persona que hubiere sido sometida a juicio criminal por resolución judicial declarada injustificadamente errónea o arbitraria por la Corte Suprema". ¿Cuál resolución judicial? La que la Corte estime que fue pertinente.

El señor Silva Bascuñán concuerda con la proposición del señor Evans.

El señor Schweitzer ( Ministro de Justicia ) advierte que dicha redacción mejora un poco la situación.

El señor Guzmán señala que, en cualquier caso, prefiere decir: " juicio criminal declarado injustificadamente erróneo ".

El señor Silva Bascuñán estima que no es el juicio fundamentalmente erróneo, sino la resolución judicial que ha generado como consecuencia el procedimiento injusto, cualquiera que sea el tipo de resolución judicial que se ha producido.

El señor Evans cree que hay que referirse más bien a la resolución judicial que al juicio -y el señor Ministro lo confirmó-, puede ser el auto encargatorio de reo, el cual puede ser erróneo o injusto, la misma característica puede tener la acusación; la misma característica puede tener la sentencia condenatoria de primera instancia y la misma característica puede tener la sentencia de segunda instancia. Cuatro resoluciones, por lo menos, que pueden haber sido, en definitiva, injustificadamente erróneas o arbitrarias, y así declararlo la Corte Suprema. Por eso, prefiere hablar de resolución judicial, porque lo que la Corte Suprema va a examinar es cuál de ellas fue injustificadamente errónea o arbitraria.

El señor Guzmán piensa que (...), no es la calificación de esa sola resolución la que, en definitiva, va a motivar el derecho o no a la indemnización, sino que es la calificación de todo un curso que representa el proceso, de toda una secuencia, porque puede ser que el auto encargatorio de reo no sea injustificadamente erróneo o arbitrario, pero lo que sí sea injustificadamente erróneo o arbitrario sea para la persona 
el curso posterior que el proceso siga, porque pueden allegarse antecedentes que hicieran, por ejemplo, que el juez de primera instancia debiera proceder de una determinada manera y no de otra, y que al actuar en otra forma, procediera con error injustificado o arbitrario, no obstante que su auto encargatorio de reo era razonablemente erróneo o tenía motivo plausible de error. Eso es muy frecuente, y eso es lo que quiere precaver.

El señor Ortúzar (Presidente) tiene la impresión de que lo primero que habría que resolver es si este derecho a indemnización va a tener lugar única y exclusivamente, como él había entendido, cuando el procesado es privado de su libertad durante el proceso como consecuencia de la encargatoria de reo. Dicho en otros términos, cabe preguntarse si va a tener lugar ese derecho de indemnización cuando no hay privación de la libertad durante el proceso y, en definitiva, se produce, como señalaba el señor Ministro, el sobreseimiento definitivo sin que haya mediado encargatorio de reo.

El señor Schweitzer (Ministro de Justicia) estima que esta situación sería injusta.

El señor Schweitzer (Ministro de Justicia) señala que es evidente que si al sujeto lo han declarado reo y lo han tenido en la cárcel tendrá mayor derecho para impetrar la indemnización. Pero si al sujeto lo han tenido en tela de juicio y "cascabeleando" durante varios meses en la prensa -" proceso que se sigue en contra fulano de tal" -, no le ha pasado nada todavía, pero lo han perjudicado enormemente, entre otras cosas, le han impedido realizar una cantidad de actividades. Agrega que debe recordarse el caso de las personas que eran inculpadas simplemente de alguna infracción a la Ley de Cambios, a las cuales se les cerraban sus cuentas corrientes en el Banco Central y no podían operar. El hecho de que no los hayan tomado presos, no hayan estado en la cárcel, no deja de haberles producido un perjuicio tremendo, como es el daño moral que los ha afectado durante varios meses en que se les ha sindicado como autores de un delito que no se ha probado nunca y que termina finalmente con el sobreseimiento.

El señor Ortúzar (Presidente) expresa que la Comisión no se había puesto en ese caso, sino que se había situado siempre en el caso de que la persona hubiere sido sometida a proceso, vale decir, que hubiere sido encargada reo y, por lo tanto, privada de la libertad.

(...) Ahora resulta que este derecho de indemnización también debiera otorgarse a aquellos que sin haber sido encargados reos, sin embargo, han sido sindicados como culpables en un juicio criminal.

El señor Ovalle expresa que en reuniones anteriores se llegó a acuerdos sobre los puntos fundamentales que debía abarcar la disposición. Señala que uno de los puntos debatidos fue el siguiente: ¿Se hacía extensiva esta indemnización a los meramente 
detenídos, o iba a constituir requisito para que operara la indemnización la circunstancia de estar encargado reo el sometido a proceso, estuviera o no detenido, porque podía no haberse resuelto la encargatoria de reo? Recuerda que al respecto se acordó que al detenido no se iba a dar este beneficio: que éste se concedería solamente a aquél que hubiera estado sometido a proceso. Entiende que ese acuerdo está vigente (..).

El señor Ortúzar (Presidente) comparte las apreciaciones del señor Ovalle, y explica que si la Mesa ha sometido a debate este asunto es porque, en realidad, surgió una interpretación distinta en relación con los acuerdos que se habían adoptado en la Comisión, en el sentido de que tampoco podía privarse del derecho a la indemnización a aquel que, sin haber estado sometido a proceso, se veía envuelto en un juicio criminal injusto. Por eso, frente a esta cuestión nueva ha invitado a los señores miembros de la Comisión a que se pronuncien sobre ella.

El señor Guzmán cree que (...) para que realmente proceda la indemnización se requiere que la persona sea sometida a proceso, no simplemente que se vea "envuelta" en un juicio ni que tenia que "soportar" un juicio criminal. Este ejemplo lo confirma. Por lo tanto, él se quedaría con la expresión "sometido a proceso", porque la encuentra más precisa, de acuerdo con el ejemplo que acaba de poner el señor Ministro.

El señor Guzmán considera que la expresión "sometida a proceso" implica el proceso entero. Lo que ya lo restringe es si se habla de resolución judicial, porque está claro que una persona no puede ser sometida a proceso sin resolución judicial. De manera que habrá una resolución judicial que lo someta a proceso, pero habrá un conjunto de otras resoluciones judiciales que configurarán el conjunto del proceso, que tiene una secuencia en el tiempo.

Entonces, si ya se ha esclarecido que lo correcto es decir "sometida a proceso", porque sólo ahí puede haber el error judicial injustificado a que se está haciendo referencia, y en segundo lugar, se supone o se parte de la base que este sometimiento a proceso proviene de resoluciones judiciales, necesariamente, ¿por qué no es más correcto y más de acuerdo a lo que la Comisión ha querido en todo momento, decir "sometido a proceso declarado injustificadamente erróneo o arbitrario", de manera que la Corte Suprema pueda pronunciarse sobre el conjunto del proceso y el conjunto de resoluciones judiciales que lo configuran?

El señor Ovalle concuerda -y cree que así se había convenido- en que debe emplearse la expresión "sometida a proceso", porque es ésta la que determina el nacimiento del juicio y no daría derecho a indemnización la circunstancia de ser meramente querellado o meramente detenido (...), pues la resolución que determina el 
nacimiento del proceso y que lo transforma en erróneo o arbitrario es aquella necesaria para que el proceso se inicie, y es la encargatoria de reo.

El señor Guzmán disiente de la opinión del señor Ovalle.

El señor Ovalle explica que él no ha dicho que sea solamente el auto de procesamiento, y lo que ha expresado es que para que el proceso sea erróneo o arbitrario tiene que serlo el auto de procesamiento, porque, si no lo es, no hay proceso erróneo o arbitrario.

El señor Guzmán disiente de la aseveración del señor Ovalle, y señala que el proceso debe ser injustificadamente erróneo.

El señor Guzmán pregunta al señor Ovalle si cree que no podría ocurrir el caso de que el auto encargatorio de reo fuera justificadamente erróneo, pero el curso siguiente del proceso configurara un error ampliamente injustificado (...).

El señor Ovalle (...) sostiene que lo que cabe declarar injustificadamente erróneo o arbitrario es el sometimiento a proceso, y ese sometimiento se produce por la encargatoria de reo (...), pues de lo contrario, se estaría cayendo en una disposición tan excesivamente amplia, por una parte, y que daría lugar a un análisis casuístico tan exagerado, por la otra, que se podría, en definitiva, provocar más problemas de los que se pretende resolver. Explica que la Comisión está dictando esta disposición con el propósito de cautelar la libertad personal, fundamentalmente. Esta disposición es la consecuencia de ese propósito: El de cautelar la libertad personal. La libertad personal se ve indudablemente afectada desde el momento en que el individuo es sometido a proceso (...).

El señor Silva Bascuñán (...) agrega que él observa el proceso penal como una especie de universo jurídico que puede tener muchos resultados y muchas facetas, una de las cuales -en proceso que puede ser perfectamente consistente como tal- ha podido generar, en alguna etapa de él o en todas, como corresponda, un resultado que es el de que una determinada persona haya estado afectada en el proceso, en circunstancias de que, debidamente expedita la justicia criminal, no debió haber sido afectada. De manera que a él le parece que debe procurarse que la Corte Suprema tenga la plenitud de la jurisdicción para determinar en qué circunstancias, por qué resolución y en qué momento se produjo la generación de este sometimiento injustificado al proceso. De modo que, debe analizarse no sólo el momento en que se produjo aisladamente la resolución que va a declarar sometido a proceso, sino que se trata de un juicio general que hay que hacer al final para ver si todo eso se produjo como resultado de un procesamiento que tiene esas condiciones. 
El señor Evans señala que procederá a hacer una relación de las conclusiones hasta el momento, por lo menos, de las primarias. Primero, en los juicios criminales pueden producirse varias resoluciones injustificadamente erróneas o arbitrarias, no sólo el auto encargatorio de reo, confirmado por el señor Ministro de Justicia hace un momento y repetido por él; segundo, lo más probable, dentro del juicio criminal, es que si hay una resolución que siempre va a aparecer como justificadamente errónea es el auto encargatorio de reo. ¿Por qué? Porque es la que requiere menos requisitos legales para su dictación, requiere solamente que esté acreditada la existencia del delito y de que existan presunciones fundadas de que la persona ha tenido participación en el hecho delictuoso.

De manera que él diría que es la resolución donde debe concurrir un menos caudal de elementos, $y$, en consecuencia, lo más probable es que sea generalmente una resolución que no admita la calificación de "injustificadamente errónea o arbitraria".

(...) Cree que lo más probable es que si se restringe la disposición solamente a la encargatoria de reo, vaya a ser mínimo el número de casos que la Corte Suprema declare injustificadamente erróneos o arbitrarios.

El señor Ovalle declara que lo ha convencido la argumentación del señor Evans.

El señor Ovalle estima que la solución en ese caso es simple: "Toda persona que hubiere sido sometida a proceso o condenada por resolución judicial declarada injustificadamente errónea o arbitraria por la Corte Suprema" .... etcétera.

El señor Evans señala que él diría una cosa más simple aún: "Toda persona que hubiere sido sometida a proceso criminal", con lo que ya no está referida a la encargatoria de reo.

El señor Ovalle cree que hay que referirse a ella, además.

El señor Ortúzar (Presidente) (...).Observa que, al parecer, la mayoría de la Comisión desea que no se limite al precepto al caso de una simple resolución que somete a proceso a una persona y que sea injustificadamente errónea o arbitraria, sino consignar de algún modo, en general, la totalidad del proceso, que es la idea del señor Evans, pues puede ocurrir, como él señalaba, que la resolución que lo encarga reo en realidad sea hasta cierto punto razonablemente justificada.

El señor Evans propone la siguiente redacción: "Toda persona que esté sometida a proceso o condenada en cualquier instancia" -por que las instancias son dos- "por resolución declarada injustificadamente errónea o arbitraria por la Corte Suprema, tendrá derecho, una vez dictado sobreseimiento definitivo" ... 
El señor Ortúzar (Presidente) expresa que entiende que el deseo o la idea del señor Evans es que, en definitiva, tenga derecho a indemnización aquel que ha sido sometido a un proceso que, en su conjunto, como decía el señor Guzmán, puede ser injustificadamente erróneo.

El señor Ovalle discrepa de la apreciación del señor Presidente, y añade que él propuso una redacción muy semejante a la del señor Evans. ¿Y cuál es la idea? La que él tuvo, por lo menos -en lo que se convenció-, es que, siendo injustificadamente errónea o injusta la encargatoria de reo o la sentencia condenatoria de cualquier instancia o de las dos, la indemnización procede en cualquiera de esas eventualidades. Esa es la idea.

El señor Ortúzar (Presidente) señala que contestará con el ejemplo puesto por el señor Evans y el señor Ministro de Justicia. Una persona es sometida a proceso. La resolución no es injustificadamente errónea. Se sigue todo un proceso del cual ella es víctima y, en definitiva, sale absuelta. No tiene derecho a indemnización, que fue, precisamente, lo que se quiso cubrir.

El señor Ovalle opina que efectivamente así sucede si la resolución que la encargó reo no es injustificada.

El señor Evans concuerda en que esa persona, en dicho caso, no tiene derecho a indemnización.

El señor Ortúzar (Presidente) considera que, entonces, esta redacción no resuelve la preocupación que señaló el señor Evans.

El señor Evans cree que la resuelve plenamente, y si la persona ha sido sometida a proceso por resolución que no es ni errónea, ni arbitraria, no tiene derecho a indemnización.

El señor Ortúzar (Presidente) considera que, entonces, significa que la disposición estaba correcta.

El señor Evans señala que lo estaba con el agregado de la condena" 20.

\section{NUEVA INTERPRETACIÓN}

Resulta indudable que la expresión sometido a proceso, incorporada por la Comisión de Estudio, no lo fue con carácter excluyente ni prohibiendo que se conceda

${ }^{20}$ Actas citadas en supra nota 6, pp. $5 \mathrm{ff}$. 
la indemnización por los errores injustificados o las arbitrariedades cometidas en el curso del proceso penal en su conjunto.

El empleo de aquella expresión se justificó en consideración al rol que al auto de procesamiento corresponde en el Procedimiento Penal Antiguo. De esta forma, resultaba impensable que una actuación injustificadamente errónea o arbitraria del Juez no fuera a concretarse o manifestarse en el referido auto de procesamiento o que no fuera a quedar constancia de aquel obrar lesivo de los derechos de las personas en esa resolución o en la sentencia condenatoria.

Tal fue, a no dudarlo, el sentido de precisar las dos resoluciones a que se alude en el artículo $19^{\circ} \mathrm{N}^{\circ} 7^{\circ}$ letra i), puesto que un error como el que cabe cometer para dar lugar a la indemnización prevista en aquella norma constitucional, no podía sino quedar en evidencia en el auto de procesamiento o, peor aún, en la sentencia condenatoria.

Con todo, el Poder Constituyente tuvo el cuidado de no emplear la expresión auto de procesamiento, sino de utilizar una locución más amplia, comprensiva del proceso penal en su integridad, como ocurre con el sometido a proceso.

Por ello, lo que cabe colegir de la historia fidedigna, es que, al emplearse la expresión sometido a proceso, no se quiso reducir el examen del obrar injustificadamente erróneo o arbitrario del juez en la causa criminal al auto de procesamiento, pues, al decir del profesor Silva Bascuñán, el proceso penal es un universo jurídico. Lo que ha ocurrido en la Comisión es que, atendido el papel cardinal que en el Antiguo Proceso Penal corresponde al auto de procesamiento, se consideró que el error no podría sino quedar patente en esa resolución clave del enjuiciamiento criminal, pero evitando referirse a ella específicamente y empleando, al contrario, una expresión denotativa de la idea de que el afectado haya sido sujeto de un proceso penal, esto es, que a su respecto se haya llevado adelante el juicio criminal, cualesquiera hayan sido las resoluciones judiciales concretas dictadas en relación con é $\left.\right|^{21}$. Basta para ello recordar lo dispuesto en el artículo $403^{\circ}$ del Código de Procedimiento Penal Antiguo, en virtud del cual, no puede elevarse a plenario un proceso, por crimen o simple delito, sino en contra de las personas sometidas a proceso ${ }^{22}$.

De lo expuesto, entonces, es menester concluir que la interpretación estricta dada por la Corte Suprema a la expresión sometido a proceso, empleada por el artículo $19^{\circ} \mathrm{N}^{\circ} 7^{\circ}$ letra i) de la Constitución, haciéndola sinónima del auto de procesamiento,

\footnotetext{
${ }^{21}$ El Diccionario de la Real Academia de la Lengua Española (Madrid, Ed. Espasa - Calpe, 1992), define someter, en su última acepción, como " hacer que una persona o cosa reciba o soporte cierta acción ". p. 1.349.

22 JORQUERA LORCA, René: Síntesis de Derecho Procesal Penal (Santiago, Ediciones Jurídicas La Ley, 1997) pp. $207-209$.
} 
no es consistente con la historia y el espíritu de la norma referida, siendo necesario revisar esa interpretación, con el objeto de dotarla de completa y extensiva aplicación, de forma tal, que se la conciba en términos que se amparen, efectivamente, los derechos del afectado y su integridad moral y patrimonial, cuando acuda a la acción especial concedida en aquel artículo.

En realidad, de la historia del precepto constitucional, latamente transcrita, es posible extraer que, cuando la Constitución se ha referido, precisa y puntualmente, a la persona que ha sido objeto de la resolución comprendida en el artículo $274^{\circ}$ del Código de Procedimiento Penal Antiguo y bastando nada más que aquella resolución ejecutoriada para producir el efecto determinado por la Carta Fundamental, ha empleado la expresión procesado, como en sus artículos $16^{\circ} \mathrm{N}^{\circ} 2^{\circ}, 19^{\circ} \mathrm{N}^{\circ} 7^{\circ}$ letra d) o $58^{\circ}$ inciso $2^{\circ}$. Asimismo, tampoco hay duda que el Poder Constituyente alude, precisamente, a la resolución judicial contemplada en el ya referido artículo $274^{\circ}$ cuando usa la expresión prisión preventiva, como lo hace en el artículo $19^{\circ} \mathrm{N}^{\circ} 7^{\circ}$ letra c).

Empero, en el artículo $19^{\circ} \mathrm{N}^{\circ} 7$ letra i) se ha empleado la locución sometido a proceso con un alcance más amplio que el de simplemente procesado o al que se alude con prisión preventiva:

"Ninguna duda cabe, por ende, de que esta primera causal de procedencia del resarcimiento fiscal en la norma in comento, "sometido a proceso", se refiere a algo más amplio que encargado reo -cosa por demás bastante lógica- a pesar de que en nuestro procedimiento ordinario por crimen o simple delito, aquélla presupone ésta, de modo que sólo se entiende procesado un individuo cuando se dicta un auto de reo en su contra" 23 .

\section{SITUACIÓN EN EL NUEVO PROCEDIMIENTO PENAL}

Cuanto se ha explicado, acerca del genuino sentido y alcance con que debe entenderse la referencia que el artículo $19^{\circ} \mathrm{N}^{\circ} 7^{\circ}$ letra i) hace al sometido a proceso, adquiere ribetes delicados cuando se advierte que, en el Nuevo Código de Procedimiento Penal, aquella resolución desaparece:

"Como consecuencia de que el proceso descansa sobre la base de la presunción de inocencia, la institución de la prisión preventiva debe ser regulada acorde con dichos principios, y en todo el proceso deben adecuarse los trámites para evitar que se incurra en declaraciones anticipadas de culpabilidad, por ello es que en el nuevo sistema

${ }^{23}$ CAROCCA PÉREZ Alex: "Reparación de los Errores y Arbitrariedades Judiciales" en XI Revista de Derecho (Valparaíso, Universidad Católica de Valparaíso, 1987) p. 210. 
desaparece el auto de procesamiento actual, resolución que en la actualidad deviene en la práctica en una declaración de culpabilidad pronunciada antes del inicio del juicio contradictorio propiamente tal (...).

La presunción de inocencia implicará, una vez vigente el nuevo proceso penal, que la prueba completa de la culpabilidad del imputado debe ser proporcionada por la acusación, pues caso contrario, habrá de dictarse sentencia absolutoria" ${ }^{24}$.

Y en términos más precisos todavía:

"El estado de inocente del individuo impide la afectación de cualquiera de sus derechos y en especial de su libertad, a título de pena anticipada por el delito que se le atribuye.

Es así que la privación de libertad durante el proceso debe ser excepcional, establecida para neutralizar el grave peligro de que el imputado abuse de su libertad para intentar obstaculizar lá acción de la justicia, o la eventualidad cierta de su fugaa, para eludir la sustanciación del proceso y el cumplimiento de la pena que se le pueda imponer.

De manera que, para mantener su naturaleza puramente cautelar, la prisión preventiva debe ser transitoria, de una duración razonable, cesando necesariamente cuando se traspasen esos límites aun cuando la sentencia no se haya dictado, pues el imputado no tiene por qué soportar en su persona la ineficacia y lentitud del sistema de justicia penal" 25 .

Pues bien, ¿quiere decir que la eliminación del auto procesamiento en el Nuevo Código de Procedimiento Penal provoca, como consecuencia imprevista de una reforma en el nivel legal, que quede sin efecto, o sea prácticamente derogado, un precepto de jerarquía constitucional, el cual, a mayor abundamiento, crea una acción y confiere el derecho correlativo para ejercerla?

Tal hipótesis, ante la sola lectura de lo preceptuado en el artículo $6^{\circ}$ inciso $1^{\circ}$, donde se consagra el Principio de Supremacía Constitucional y, consecuencialmente, el de Subordinación del resto de las normas jurídicas, incluyendo la ley, tiene que ser, in limine, descartada.

\footnotetext{
${ }^{24}$ BANDA VERGARA Alfonso: "Derechos Fundamentales del Imputado: En la Actualidad y en el Nuevo Proceso Penal" en (Número Especial) Revista de Derecho (Valdivia, Facultad de Ciencias Jurídicas y Sociales de la Universidad Austral de Chile, 1999) p. 107.

25 JARA MULLER Juan Javier: "Principio de Inocencia. El Estado Jurídico de Inocencia del Imputado en el Modelo Garantista del Proceso Penal" en (Número Especial) Revista de Derecho (Valdivia, Facultad de Ciencias Jurídicas y Sociales de la Universidad Austral de Chile, 1999) p. 55.
} 
Cierto es que la eliminación del auto de procesamiento, en el Nuevo Código, impacta en diversas disposiciones constitucionales.

"En el nuevo Código Procesal Penal no se hace referencia al reo o procesado. No existe dentro de aquel sistema procesal penal resolución alguna que pudiera estimarse análoga al auto de procesamiento.

Lo anterior no es indiferente, pues la Constitución Política alude, en diversas disposiciones, al procesado o sometido a proceso. También utiliza la expresión ciudadano con derecho a sufragio (...).

Esto trae consigo significativas consecuencias en el orden institucional" 26 .

Indudablemente, la cuestión puede resultar algo más controvertida cuando el procesamiento constituye, de acuerdo a la Carta Fundamental, un requisito o condición del que pende la aplicación de una sanción, pues aquellos preceptos constitucionales deben siempre interpretarse y aplicarse restrictivamente. Empero, no se sigue la misma controversia cuando para el sometido a proceso deriva la vigencia y aplicación de una norma que confiere un derecho de jerarquía constitucional, como es el que otorga el artículo $19^{\circ} \mathrm{N}^{\circ} 7^{\circ}$ letra i) de la Carta Fundamental.

En este caso, no cabe interpretación alguna que rebaje la jerarquía del derecho y de la acción tendiente a hacerlo efectivo y menos del precepto que lo contiene. No puede, por efecto tácito ni aún expreso de una norma legal, desaparecer un derecho constitucionalmente configurado y aún colocarse en entredicho su procedencia y aplicabilidad. A la luz del Principio de Supremacía Constitucional, de la Fuerza Normativa de la Carta Fundamental y, en la especie, del Principio de Responsabilidad, todos fundantes del Estado de Derecho, esto es, del Estado donde ninguna arbitrariedad queda impune, tal interpretación debe ser excluida:

"Interesante es destacar que la finalidad primordial de esta nueva norma constitucional es proteger la dignidad de la persona humana, como lo ha reconocido la jurisprudencia:

‘...el alcance del derecho que instaura la Constitución Política de 1980, en la letra i) del $\mathrm{N}^{\circ} 7^{\circ}$ del artículo $19^{\circ}$, no es otro que velar por y proteger la dignidad de las personas, resarciéndoles los perjuicios efectivos o simplemente morales que hubiesen

\footnotetext{
${ }^{26}$ PFFEFER URQUIAGA, Emilio: "Código de Procedimiento Penal " en El Mercurio de Santiago, publicado el 12 de enero de 2001, p. A2.
} 
sufrido por una resolución injustificadamente errónea o arbitraria, que los hubiera sometido a proceso a satisfacer condena' "27.

Lo anterior, en primer lugar, por los ya aludidos Principios de Supremacía Constitucional, Fuerza Normativa y Responsabilidad, todos valores de la máxima jerarquía en nuestro Ordenamiento Jurídico. Asimismo y en segundo lugar, porque la debida reparación de los daños causados por actuaciones lesivas de la libertad personal, se encuentra reconocida en tratados internacionales ratificados por Chile y que se encuentran vigentes. Esos preceptos, ciertamente, tienen jerarquía constitucional, v. gr. el artículo $9^{\circ}$ párrafo $5^{\circ}$ del Pacto Internacional de Derechos Civiles y Políticos, al tenor del cual "toda persona que haya sido detenida o presa, tendrá el derecho efectivo a obtener reparación".

En fin, la evolución en la tutela de los derechos fundamentales y, consecuencialmente, en el desarrollo y profundización de las garantías, sobre todo las de jerarquía constitucional, constituye un derrotero que no puede eludirse al analizar lo preceptuado en el artículo $19^{\circ} \mathrm{N}^{\circ} 7^{\circ}$ letra i) en relación al Nuevo Procedimiento Penal:

"El arrollador avance en la posición de las garantías explota al mismo tiempo a escala global.

Son numerosas las causas concurrentes a esa deseada rejerarquización y fuerza operativa de las garantías.

$1^{\circ}$ La energía que a ese potenciado sistema le suministran dos poderosas ideasfuerza impulsoras: a) la constitucionalización de las más significativas como son la de la defensa en juicio (el proceso justo), el amparo, el habeas data, y en sí la acción procesal, por una parte $\mathrm{y}$ b) el continuo enriquecimiento de sus contenidos y la dinámica de los documentos y declaraciones (con orientación general y tendencia vinculante a través de Tratados, principios y directivas jurisprudenciales) de entes públicos y órganos jurisdiccionales transnacionales, que sellan la suerte homogénea y simultánea de una cultura garantística y que se ha galvanizado en vastas comunidades regidas por expresiones normativas, pautas y estándares hondamente enraizados en ellas, que se interrelacionan y actúan de manera recíproca.

Obviamente, hay numerosos puntos débiles en la teoría y en la praxis de las garantías, pero es igualmente remarcable cuánto es lo que se va haciendo en la dirección correcta y dentro del sistema democrático. La impronta de estar alertas y dispuestos a impedir que cualquier golpe de tensión fuerce a un retroceso, o a una

${ }^{27}$ CEA EGAÑA José Luis: El Sistema Constitucional de Chile. Sintesis Crítica (Valdivia, Facultad de Ciencias Jurídicas y Sociales de la Universidad Austral de Chile, 2000) p. 146. 
minivaluación de su vigencia, ha sido comprendida en el doloroso proceso de la historia reciente " 28 .

Este ha sido también el planteamiento de nuestra doctrina:

"(...) se entiende por garantías las acciones y recursos procesales, cuya eficaz deducción, decisión y cumplimiento por la Magistratura, en virtud de su Poder de Imperio, permite que cobren seguridad y realidad las Declaraciones de Derechos y Deberes Fundamentales. $Y$ esas acciones y recursos deben ser eficaces, para lo cual tienen que hallarse franqueadas, en el ordenamiento jurídico, las oportunidades de deducirlas, cautelar o preventivamente y ex post, es decir, con sentido rectificador o sucesivo, mal llamado represivo. Pero, más todavía, ello debe ocurrir no sólo en la sede judicial, sino que también ante todo órgano que ejerza jurisdicción (...).

Es fácil admitir que poco o nada sirven aquellas Declaraciones cuando no van acompañadas de las garantías aludidas. Estas, por sí solas, tampoco basta, pues se precisa, además un sistema completo y expedito de asesoría y apoyo a la acción y defensa jurídica que las vuelvan eficaces. Empero, asumiendo que ese sistema existe, entonces podemos afirmar que las garantías son las que, en la práctica, infunden vigencia a dichas Declaraciones, llevándolas de la condición de tal, esto es, de proclamaciones solemnes en textos brillantes, a la calidad de Principios y Normas eficaces y efectivos en la realidad cotidiana, sea de normalidad o de emergencia crítica en la convivencia del Estado Democrático "29.

Cierto es y esto no puede silenciarse, aunque con esperanza en la pronta recapacitación, que, a diferencia de la tendencia universal, en nuestro país se ha involucionado hacia la desprotección de los derechos fundamentales:

"En realidad, los cambios aludidos marcan el punto culminante en lo concerniente al debilitamiento de tal acción cautelar, al que se ha llegado desde la dictación del Auto Acordado del 27 de junio de 1992 (...)"30.

En suma, la exigencia constitucional en cuanto a que una persona, para tener derecho a la indemnización por error judicial, debe haber sido sometida a proceso tiene que ser interpretada en sentido amplio, esto es, que haya sido sujeta a un proceso penal, o sea, que a su respecto, cualesquiera sean las resoluciones que la hayan afectado, se haya desarrollado, total o parcialmente, un proceso penal, pues sólo esa interpretación resulta coherente con la Carta Fundamental y su historia fidedigna, así

\footnotetext{
${ }^{28}$ MORELLO, Augusto Mario: Constitución y Proceso (Buenos Aires, Abeledo-Perrot, 1998 ) pp. 129 - 130 y 133.

${ }^{29}$ CEA EGAÑA, José Luis citado en supra nota 27 , pp. 84 - 85 .

${ }^{30}$ Id., p. 166.
} 
como con los principios garantísticos que contempla y resguarda, sobre todo, el Nuevo Procedimiento Penal.

\section{SOBRESEIMIENTO DEFINITIVO O SENTENCIA ABSOLUTORIA}

El tercer requisito que exige la Constitución, para hacer procedente la indemnización que contempla en su artículo $19^{\circ}^{\circ} 7^{\circ}$ letra i), consiste en que el sometimiento a proceso o la condena haya quedado sin efecto, en virtud de otra resolución judicial, sea ésta pronunciada por el mismo Tribunal o por otro que revise la resolución expedida por aquél. Esta otra resolución judicial debe consistir en un sobreseimiento definitivo o en una sentencia absolutoria.

Acudiendo, nuevamente, al Código de Procedimiento Penal, es posible dilucidar en qué consisten aquellas dos especies de resolución judicial, propias del proceso criminal: El sobreseimiento definitivo es la resolución judicial, en virtud de la cual se pone término al procedimiento judicial en lo criminál ${ }^{31}$; y la sentencia ábsolutoria ès la resolución judicial, pronunciada en esa especie de proceso, en virtud de la cual se resuelve que el afectado no ha tenido responsabilidad en los hechos que se le imputan ${ }^{32}$.

En semejante sentido se regulan ambas instituciones en el Nuevo Procedimiento Penal. Así, mientras la sentencia absolutoria se encuentra normada en los artículos $339^{\circ}$ y siguientes del Nuevo Código de Enjuiciamiento Criminal; el sobreseimiento definitivo está contemplado en su artículo $250^{\circ 33}$.

\footnotetext{
${ }^{31}$ Artículo $406^{\circ}$ inciso $1^{\circ}$ del Código de Procedimiento Penal.

El artículo $408^{\circ}$ del mismo Código señala que "El sobreseimiento definitivo se decretará " :

" 1 . Cuando, en el sumario, no aparezcan presunciones de que se haya verificado el hecho que dio motivo a formar causa;

$2^{2}$. Cuando el hecho investigado no sea constitutivo de delito;

$3^{\circ}$. Cuando aparezca claramente establecida la inocencia del procesado;

$4^{2}$. Cuando el procesado esté exento de responsabilidad en conformidad al artículo $10^{\circ}$ del Código Penal o en virtud de otras disposiciones legales:

$5^{2}$. Cuando se haya extinguido la responsabilidad penal del procesado por alguno de los motivos establecidos en los números $1^{2}, 3^{2}, 5^{2}$ y $6^{2}$ del artículo $93^{\circ}$ del mismo Código;

62. Cuando sobrevenga un hecho que, con arreglo a la ley, ponga fin a dicha responsabilidad; $y$

$7^{2}$. Cuando el hecho punible de que se trata haya sido ya materia de un proceso en que haya recaído sentencia firme que afecte al actual procesado".

${ }^{32}$ Artículos $500^{\circ}$ y siguientes del Antiguo Código de Procedimiento Penal.

${ }^{33}$ Dispone este precepto que:

"El juez de garantía decretará el sobreseimiento definitivo:

a) Cuando el hecho investigado no fuere constitutivo de delito;
} 
Esta última norma es prácticamente idéntica a la que hoy se contempla en el artículo $408^{\circ}$ del Antiguo Código, salvo que: Por una parte, se elimina la que aparecía como la primera causal de sobreseimiento, esto es, cuando en el sumario no aparezcan presunciones de que se haya verificado el hecho que dio motivo a formar causa; $y$, de otra, las referencias que, en el Código de 1906, se hacían al procesado se cambian ahora por el imputado.

Esta segunda diferencia, sustantiva por cierto y coherente con la eliminación del auto de procesamiento, en los términos cardinales que lo contemplaba el Antiguo Código, permite afirmar, haciendo coherente los principios y fines garantísticos del Nuevo Procedimiento Penal con la protección de los derechos humanos propugnada por nuestra Constitución y los tratados internacionales, ratificados por Chile y que se encuentran vigentes, que desde el momento que una persona tenga la calidad de imputado -esto es, desde que se le atribuya participación en un hecho punible ${ }^{34}$ - podrá impetrar, si ello se funda en un obrar injustificadamente erróneo o arbitrario, la indemnización contemplada en el artículo $19^{\circ} \mathrm{N}^{\circ} 7^{\circ}$ letra i) de la Carta Fundamental.

En efecto, desde que se es imputado, en el Nuevo Código, se está sometido a proceso, en los términos amplios y garantísticos ya explicados. Así, el imputado es una persona que se encuentra sujeto a un proceso penal, debiendo soportar la carga que ello implica. Por eso, cuando dicha carga o gravamen se vincula con actuaciones injustificadamente erróneas o arbitrarias de los órganos encargados de llevar adelante el proceso penal, entonces, surge el derecho a ser indemnizado, conforme al artículo $19^{\circ} \mathrm{N}^{\circ} 7^{\circ}$ letra i) de la Constitución y, si no se cumplen todos los requisitos exigidos por la Carta Fundamental, en ese precepto, entonces, el afectado queda habilitado para acudir al artículo $5^{\circ}$ de la Ley $N^{\circ} 19.640$, si el agente autor del agravio es el Ministerio Público; a las acciones reparatorias comunes, si el autor del agravio es el Juez, o a la acción especial contemplada en el artículo $38^{\circ}$ inciso $2^{\circ}$ de la Constitución, si el agente forma parte de la Administración, como ocurre con las policías.

b) Cuando apareciere claramente establecida la inocencia del imputado:

c) Cuando el imputado estuviere exento de responsabilidad criminal en conformidad al artículo $10^{\circ}$ del Código Penal o en virtud de otras disposición legal;

d) Cuando se hubiere extinguido la responsabilidad penal del imputado por alguno de los motivos establecidos en la ley:

e) Cuando sobreviniere un hecho que, con arreglo a la ley, ponga fin a dicha responsabilidad; $y$

f) Cuando el hecho de que se tratare hubiere sido ya materia de un procedimiento penal en el que hubiere recaído sentencia firme respecto del imputado".

${ }^{34}$ Artículo $7^{\circ}$ inciso $1^{\circ}$ del Nuevo Código de Procedimiento Penal. 


\section{DECLARACIÓN DE LA CORTE SUPREMA}

El último requisito para que resulte procedente impetrar la acción indemnizatoria consiste en que la Corte declare que el sometido a proceso, en el sentido amplio que se ha explicado, o condenado lo haya sido en forma injustificadamente errónea $o$ arbitraria.

Sin lugar a dudas, es en nexo con este requisito donde se ha centrado el debate en los casos concretos presentados ante la Corte Suprema, particularmente en cuanto a determinar el significado de las expresiones empleadas por el Poder Constituyente. Indudablemente, para realizar dicha labor hermenéutica, resulta menester acudir a la historia fidedigna del precepto, a la doctrina y a la jurisprudencia que se ha pronunciado sobre el particular. Ello porque, las expresiones injustificadamente erróneo y arbitrario, son conceptos jurídicos abiertos o indeterminados ${ }^{35}$.

En punto a la historia fidedigna resulta preciso transcribir los anales siguientes:

“El señor Silva Bascuñán (...) Finalmente, estima que los términos "injustificadamente errónea", que usa el señor Evans, son aceptables. En cuanto a la arbitrariedad, hay un principio de culpa o de dolo y, en consecuencia, existirán otros mecanismos de responsabilidad que sancionen esa conducta, los cuales deberán establecerse en otra disposición. En este precepto sólo debe consagrarse el derecho a la indemnización que provenga del error liso y llano, o sea, la equivocación que se ha producido dentro del cuidado y de la buena fe, porque la arbitrariedad, en cierto sentido, ya da la idea de culpabilidad o dolo en la actuación y en ese caso juega otro sistema de responsabilidad.

El señor Guzmán manifiesta que (...) no cualquier error judicial deba dar lugar a esta indemnización, sino que debe tratarse de un error judicial calificado, vale decir, un error judicial manifiestamente injustificado o arbitrario, lo cual sitúa el problema en una órbita bastante más realista que aquélla en que lo situó el constituyente de 1925 .

(...) desea clarificar este concepto. En su opinión, se trata de un error grueso, craso, como, decía el señor Ortúzar en la sesión pasada. Puede no haber dolo ni culpa. Cuando se está en presencia de dolo o culpa, se está en presencia de la segunda hipótesis, que es la arbitrariedad. Ahí se daba por supuesta la idea de que, no obstante

${ }^{35}$ DUCCI CLARO Carlos: Interpretación Juridica (Santiago, Ed. Jurídica de Chile, 1989) p. 78.

Señala este autor que " (...) hay palabras cuyo significado es impreciso o múltiple; otras, cuyo contenido varía. El lenguaje es un elemento vivo que cambia a través del tiempo. Va perdiendo palabras que caen en desuso; se va enriqueciendo con otras que nacen de la evolución del medio social o del progreso, de la necesidad de referirse a nuevas ideas, productos o técnicas. Por último, una misma palabra puede ir cambiando de significación o comprender nuevas acepciones " (p. 115). 
que el Estado indemniza al afectado, puede accionar contra el juez, porque se produce una situación enteramente distinta. Pero aquí, puede haber indemnización sin que haya dolo ni culpa de parte del juez, habiendo simplemente un error grave, categórico, manifiesto.

Asimismo, el señor Guzmán declara que (...) lo que preocupa es que se trate de un error judicial craso, injustificado, desde el punto de vista intelectual. En seguida, declara que estaría satisfecho con el término "injustificado", siempre que se diera a este término una acepción intelectual y no moral. No se trata de dolo o culpa; se trata de que no haya justificación intelectual razonable para haber cometido ese error. Que sea un error de la persona que procede en forma razonable, acertada. Eso es lo que entiende con el término "injustificado".

El señor Evans señala que la resolución puede ser claramente errónea, manifiestamente errónea y gravemente errónea, y no obstante ello ser justificadamente errónea, porque pueden haber sido de tal naturaleza las pruebas que los testigos allegaron para configurar la culpabilidad del sometido a proceso, que realmente el juez no haya tenido otra cosa que proceder de esa manera. Su error es justificado. ¡Cómo va a haber error judicial si al juez se le brindaron este cúmulo de pruebas circunstanciales o de antecedentes que lo llevaron a la convicción de culpabilidad o de elementos que configuraron presunciones de tal naturaleza que no aparecía otra solución que la encargatoria de reo $y$, en definitiva, la sentencia condenatoria de primera instancia! El error aparece como justificado. Pero ¿cuándo es injustificado el error? Cuando no hay elementos que intelectualmente a una mente normal puedan haberla llevado a la conclusión a que llegó el juez. Esa es la arbitrariedad.

El señor Silva Bascuñán cree que la palabra "injustificada" se puede entender en dos sentidos: Falta de fundamento racional y falta de contenido de justicia. Entonces, al emplear aquí la palabra "injustificadamente", ella no tiene otro sentido que el de falta de fundamento racional y grave y no relación de justicia" ${ }^{36}$.

La doctrina que se ha pronunciado sobre el tópico ha explicado que:

"Estamos en presencia de un error injustificado; esto es, grave, más aún, grosero, cuando habiendo tenido el juez la intención de sustentar su acto jurídico terminal -la sentencia- en una norma de Derecho, a pesar suyo equivocadamente y por conocer muy somera e imperfectamente el Derecho, ha errado en su propósito, cometiendo una irregularidad manifiesta e inconcebible de parte de un órgano, remoto, se encontraría en una inadecuada gestión de la función pública jurisdiccional. En cambio, cuando el vicio es manifiestamente arbitrario, la situación es distinta, aunque

${ }^{36}$ Actas citadas en supra nota 6, sesión 119, pp. 9-10, 19 y 21 . 
las consecuencias sean idénticas, es decir, la obligación de indemnizar todo daño causado. La arbitrariedad se produce, en este caso, por la circunstancia evidente de que el juez al fallar no exteriorizó haber tenido la menor intención, inquietud o el más elemental propósito de sustentar su acto terminal sobre una norma de Derecho. En tal supuesto, la arbitrariedad no es sino la consecuencia del capricho de un funcionario, el cual, sintiéndose por encima del Derecho o, en todo caso, no ligado por aquél, deliberadamente lo ignora, a punto tal, que no lo toma ni siquiera como referencia orientadora del contenido de la sentencia condenatoria" ${ }^{37}$

A su turno, la Corte Suprema ha ido precisando las expresiones injustificadamente errónea o arbitraria que se emplean en el artículo $19^{\circ} N^{\circ} 7^{\circ}$ letra i) de la Constitución, al señalar:

"Que aunque el precepto constitucional cuya aplicación se pide por el Sr. Alfonso Stephens emplea una locución de difícil inteligencia, se entiende que el pensamiento de los Constituyentes es que el error cometido en la resolución declaratoria de reo que da origen a la indemnización debe ser inexplicable, semejante al que el Código Civil en sus artículos $122^{\circ}, 667^{\circ}$ y $668^{\circ}$ inciso $2^{\circ}$ describe con la expresión "sin justa causa de error" contraria a la otra de "con justa causa de error" 38.

En otro pronunciamiento, la más Alta Magistratura ha sostenido que:

"Como lo previene el pertinente precepto de la Constitución Política, para que esta Corte resuelva que procede la indemnización se requiere -en el caso- que la resolución de procesamiento sea arbitraria o injustificadamente errónea, es decir, que haya sido dictada por un mero capricho o por una voluntad no gobernada jurídicamente por la razón, sin base procesal de donde extraer algún dato o accidente de convicción que sirviera al Juez para motivarla; o, de otro modo, que aun cuando la resolución fuese errónea, el error carecería de justificación, entendiéndose así que el desacierto jurídico se encontrara desprovisto de toda medida que, de algún modo, lo hiciera comprensible" ${ }^{39}$.

${ }^{37}$ CALDERA DELGADO Hugo: Sistema de la Responsabilidad Extracontractual del Estado en la Constitución Política de 1980 (Santiago, Ed. Jurídica de Chile, 1982) pp. 31-32. Léase, GUZMÁN ERRÁZURIZ Jaime: "Indemnización por Error Judicial" en El Mercurio de Santiago, publicado el 12 de abril de 1981, p. 2. En términos más amplios y no sólo referidos al proceso penal, léase PICÓ I JUNOY Joan: Las Garantías Constitucionales del Proceso (Barcelona, Ed. Bosch, 1997) pp. 61, 62 y 63-64; y FERNÁNDEZ GONZÁLEZ Miguel Angel: "Recurso de Protección y Jurisdicción Doméstica: Un Principio de Solución " en XXVI Revista Chilena de Derecho (1999) pp. 774 - 775.

${ }^{38}$ Considerando $8^{\circ}$ de la sentencia pronunciada el 10 de enero de 1984 , reproducida en Gaceta Jurídica No 43 (enero de 1984) pp. $38-40$

${ }^{39}$ Considerando $4^{\circ}$ de la sentencia pronunciada el 20 de junio de 1986, reproducida en Gaceta Jurídica N ${ }^{\circ} 72$ (1986) pp. 69 - 71. Léanse, en el mismo sentido, el considerando $4^{\circ}$ de la sentencia pronunciada el 22 de enero de 1988, reproducida en Gaceta Jurídica $N^{\circ} 91$ (1988) pp. 51- 53; el considerando $9^{\circ}$ de la sentencia pronunciada el 7 de 
Siendo todavía más concretos, la Corte ha ido configurando casos o situaciones en las cuales se está de frente a un sometimiento a proceso o a una sentencia condenatoria injustificadamente errónea 0 arbitraria ${ }^{40}$ : Cuando del mérito del proceso no surgen los antecedentes indispensables para sostener el fallo en cuanto a las exigencias mínimas para dar por probados los hechos atribuidos al procesado; cuando no existen los fundamentos legales o doctrinales para calificar el delito y sus circunstancias; cuando tampoco existen las razones fácticas y de derecho para atribuir al afectado algún grado de participación en ellos; cuando la sentencia impugnada contiene consideraciones y conclusiones separadas de la realidad del proceso, conteniendo errores sin justificación o que fuera el producto de la imaginación arbitraria de su autor; cuando se atribuye carácter típico a los hechos referidos, en circunstancias que esos hechos que carecen de tal naturaleza; cuando no se han analizado, acuciosa y detenidamente, los antecedentes que se invocan para dar por acreditada la comisión de un delito, supuesto básico del procedimiento penal; cuando se ha atribuido, erróneamente, carácter típico a hechos que sólo aparecen reprochables desde el punto de vista administrativo o funcionario; cuando se aplica una ley penal derogada y ya inexistente; o cuando la resolución se apoya en elementos de prueba que en realidad no lo son.

Con todo y a pesar de la variedad de los casos mencionados, en la práctica, la Corte Suprema ha sido exigente para hacer lugar a la acción constitucional deducida por el afectado. Aquella posición de la Corte, sustentada fundamentalmente en la historia fidedigna que se ha transcrito, tiene que ser rectificada.

Al efecto, resulta menester distinguir las dos causales contempladas en el artículo $19^{\circ} \mathrm{N}^{\circ} 7^{\circ}$ letra i): Por una parte, que el obrar judicial, al haber sometido a proceso o condenado, haya sido injustificadamente erróneo; y, de otra, que haya sido arbitrario. Distinción que resulta fundamental, desde luego, porque el adverbio injustificadamente es sólo aplicable a lo erróneo y no a lo arbitrario.

Siendo así, es cierto que no cualquier error del juez puede dar lugar a la indemnización que confiere el artículo $19^{\circ} \mathrm{N}^{\circ} 7^{\circ}$ letra i) de la Constitución, sino que debe tratarse de una equivocación injustificada. Empero, lo injustificado no es

julio de 1989, reproducida en Gaceta Jurídica N 109 (1989) pp. 55 - 58; y el considerando $6^{\circ}$ de la sentencia pronunciada el 29 de enero de 1993, reproducida en XC Revista de Derecho y Jurisprudencia 2 p., S. 5, pp. 20 24.

${ }^{40}$ Léanse el considerando $7^{\circ}$ de la sentencia pronunciada el 29 de enero de 1993, reproducida en XC Revista de Derecho y Jurisprudencia 2 p., S. 5, pp. 20-24; los considerandos $13^{\circ}$ y $14^{\circ}$ de la sentencia pronunciada el 25 de julio de 1999, reproducida en LXXXVI Revista de Derecho y Jurisprudencia 2 p., S. 5, pp. 85 - 91 ; y los considerandos $10^{\circ}$ y $11^{\circ}$ de la sentencia pronunciada el 5 de diciembre de 1990, reproducida en LXXXVII Revista de Derecho y Jurisprudencia 2 p., S. 5, pp. 184 - 189. Asimismo, véase el Repertorio de Legislación y Jurisprudencia Chilenas. Constitución Política de la República de Chile 1980 (Santiago, Ed. Jurídica de Chile, 1993) pp. $49-50$. 
sinónimo, como se ha entendido usualmente, de un error craso, gravísimo, anormal o, en fin, producto de una mente carente de mínimos elementos de conciencia, lógica o razonabilidad, sino que, antes y al contrario, dice relación con lo que no encuentra soporte, apoyo o base en el proceso. Como cuentan que enseñaba don Fernando Alessandri, lo que no está en el proceso no está en el mundo.

En efecto, si lo injustificado es lo que no se corresponde con la justicia y la razón ${ }^{41}$ y atendido que el obrar carente de justificación se ha cometido en el desarrollo de un procedimiento criminal, entonces, lo que no se corresponde con el contenido del proceso, en cuanto a los hechos que en él constan y al Derecho que se debe aplicar, es lo que hace que las actuaciones y decisiones reprochadas sean injustificadas.

Así, lo injustificadamente erróneo es la decisión, actuación o conducta que no puede justificarse o sustentarse en el expediente y que, por ende, constituye un error, pues, tratándose de un procedimiento judicial, su fundamento o explicación no se encuentra en los hechos o en el Derecho que consta en el expediente, sino en consideraciones ajenas a los autos, lo cual, por ese solo hecho, debe reputarse grave. Como lo ha expresado la Corte Suprema, v. gr., cuando la sentencia impugnada contiene consideraciones y conclusiones separadas de la realidad del proceso, conteniendo errores sin justificación o que son producto de la imaginación de su autor.

A su turno, la arbitrariedad debe ser entendida conforme al concepto general con que ella ha sido empleada por el Poder Constituyente a lo largo de todo el Código Político. En este sentido, haber sometido a proceso o condenado a una persona será arbitrario cuando el obrar del juez carezca de motivación, sustento, lógica o razonabilidad, obedeciendo nada más que al capricho o la inquina.

Por ello, puede incurrirse en arbitrariedad cuando, no obstante hallarse soporte en el expediente $y$, por ende, no pudiendo calificarse el error como injustificado, carezca de lógica o razonabilidad obrar como lo ha hecho el Tribunal que incurrió en el acto arbitrario, v. gr., cuando en autos consta que el afectado ha incurrido en una conducta antijurídica y se lo somete a proceso, en circunstancias que, como ha señalado la Corte, la conducta aparece reprochable sólo en sede administrativa o disciplinaria y no es constitutiva de delito.

En resumen, el error del juez carecerá de justificación cuando, cualquiera sea su entidad, alcance o extensión, no pueda sostenerse en los hechos que constan o en el Derecho que ha sido invocado en el proceso. Y será arbitrario cuando resulte carente de razonabilidad, lógica o justicia, v. gr. cuando siendo procedente aplicar lo preceptuado en el artículo $279^{\circ}$ bis del Antiguo Código de Procedimiento Penal no se haga.

${ }^{41}$ Diccionario citado en supra nota 21, pp. 825 y 859. 


\section{REFERENCIA AL ARTÍCULO 5 DE LA LEY N 19.640}

Finalmente, es preciso señalar que, en el Nuevo Sistema de Enjuiciamiento Penal ${ }^{42}$, se ha contemplado, expresamente, la responsabilidad del Estado por las conductas injustificadamente erróneas o arbitrarias del Ministerio Público ${ }^{43}$.

Al respecto, consta de la historia fidedigna del precepto referido que:

"Uno de los principios ya aceptados por la doctrina y la jurisprudencia es que el Estado debe responder por el daño que cause a las personas con su actividad, u omisión, en su caso. Nuestra Constitución Política la consagra en el artículo $38^{\circ}$, inciso segundo, en lo que concierne a las acciones u omisiones de la Administración, y en el artículo $19^{\circ} \mathrm{N}^{\circ} 7^{\circ}$ letra i), en cuanto a las resoluciones judiciales que afecten el derecho a la libertad personal y a la seguridad individual, en la forma que allí se señala.

Coincidió la Comisión en que la transcendencia de las funciones que la Carta Fundamental encomienda al Ministerio Público y la posibilidad expresa que ella contempla en cuanto a que, en el desempeño de su actividad, realice actos que priven, restrinjan o perturben el ejercicio de derechos fundamentales, aunque para ello se requiera autorización judicial previa, hace indispensable regular la responsabilidad correlativa y no dejar entregada esta materia a la discusión doctrinaria y a las

\footnotetext{
${ }^{42}$ Sobre el tópico, léanse POBLETE ITURRATE Orlando: "Nuevos Tribunales en lo Penal y Ministerio Público", pp. 3 - 19; RIEGO RAMÍREZ Cristián: "La Etapa de Investigación en el Nuevo Proceso Penal", pp. 23 - 39; LÓPEZ MASLE Julián: "Formas Alternativas de Solución del Conflicto Penal", pp. 43-69; BOFILL GENZSCH Jorge: "Preparación del Juicio Oral y Juicio Oral", pp. 73-87; y CAROCCA PEREZ Alex: "Los Recursos en el Nuevo Proceso Penal", pp. 91 - 119, todos en Colegio de Abogados de Chile A.G.: Seminario "Las Reformas del Proceso Penal " ( Santiago, 2000 ).

Asimismo, PIEDRABUENA RICHARD Guillermo: "Función del Ministerio Público en la Realización del Estado de Derecho en Chile", pp. 11 - 16; ALVEAR VALENZUELA Maria Soledad: "La Reforma Procesal Penal en el Marco del Desarrollo Institucional para el Nuevo Siglo", pp. 17 - 20; COFRÉ LAGOS Juan O.: "Sobre la Potestad Punitiva del Estado, Legitimidad y Racionalidad". pp. 21 - 29; OBANDO HERRERA Sandra Waleska: "EI Sistema Acusatorio y el Proyecto de Reforma Procesal Penal", pp 31 - 39; CEA EGAÑA José Luis: "Fisonomía Constitucional del Ministerio Público en Chile", pp. 59 - 66: PEDRAZ PENALVA Ernesto: "Participación Popular en la Justicia Penal", pp. 67 - 93; FERRADA BÓRQUEZ Juan Carlos y ZÚÑIGA AÑAZCO Yanira: "El Régimen Probatorio y los Derechos Fundamentales en el Proyecto de Código Procesal Penal Chileno ", pp. 133 - 139; QUINTANA Juan: "La Defensa Penal en el Nuevo Ordenamiento Procesal Penal Chileno", pp. 141 - 161; y FERRADA BÓRQUEZ Juan Carlos: "La Reforma Procesal Penal y su Impacto en la Organización y Estructura del Estado-Poder Público Chileno: Algunas Reflexiones Preliminares", pp. 163 - 176, todos en (Número Especial) Revista de Derecho (Valdivia, Facultad de Ciencias Juridicas y Sociales de la Universidad Austral de Chile, 1999).

${ }^{43} \mathrm{El}$ artículo $5^{\circ}$ de la Ley $N^{\circ} 19.640$. Orgánica Constitucional del Ministerio Público, publicada en el Diario Oficial el 15 de octubre de 1999, dispone:

"El Estado será responsable por las conductas injustificadamente erróneas o arbitrarias del Ministerio Público.

La acción para perseguir esta responsabilidad patrimonial prescribirá en cuatro años, contados desde la fecha de la actuación dañina.

En todo caso, no obstará a la responsabilidad que pudiese afectar la fiscal o funcionario que produjo el daño, y. cuando haya mediado culpa grave o dolo de su parte, al derecho del Estado para repetir en su contra "
} 
decisiones judiciales, necesariamente casuísticas, como única forma de crear seguridad jurídica.

Al efecto, creyó que una fórmula era establecer la obligación del Estado de indemnizar los daños causados por el Ministerio Público por acciones $u$ omisiones arbitrarias, ilegales o manifiestamente erróneas. Estos conceptos no son novedosos para nuestro ordenamiento constitucional, ya que han experimentado un importante período de decantación en institutos como el recurso de protección y la propia responsabilidad por la actividad jurisdiccional antes aludida.

Con todo, siendo esta materia de iniciativa exclusiva de S.E. el Presidente de la República, el Primer Mandatario formuló la indicación número 1, para consignar que el Estado será responsable por los "actos injustificadamente erróneos o arbitrarios del Ministerio Público".

La Comisión aceptó ese criterio, que guarda concordancia con la responsabilidad del Estado por su actividad jurisdiccional, la cual procede respecto de aquella resolución que sea "injustificadamente errónea o arbitraria", sin perjuicio de que esta última se encuentra constitucionalmente restringida a los casos que hayan redundado en el sometimiento a proceso o condena del afectado. No obstante, le preocupó que, al mencionar los actos, queden excluidas las omisiones en que incurra el Ministerio Público. Por tal motivo, optó por hacer referencia a "las conductas", en el entendido de que, de esta forma, se está comprendiendo tanto a las acciones como a las omisiones de este organismo " 44 .

Desde luego, la disposición legal viene a confirmar el Principio General de Derecho, en virtud del cual, cualquiera sea el órgano estatal causante de un perjuicio, el afectado tiene derecho al resarcimiento de los perjuicios ${ }^{45}$. La cuestión estriba, sin embargo, en aclarar que la norma referida no excluye la procedencia de la acción contemplada en el artículo $19^{\circ} \mathrm{N}^{\circ} 7^{\circ}$ letra i) de la Constitución cuando el agente causante del obrar injustificadamente erróneo o arbitrario haya sido el Ministerio Público.

En efecto, la norma constitucional, bajo la estructura del Antiguo Procedimiento Penal, sólo hacía concebible que el autor del agravio fuera el Juez. Empero y atendida la configuración del Nuevo Enjuiciamiento Criminal, donde las facultades investigativas quedan separadas de las vinculadas con el juzgamiento, no

\footnotetext{
${ }^{44}$ Segundo Informe de la Comisión de Constitución, Legislación, Justicia y Reglamento del Senado, recaído en el proyecto de ley, en segundo trámite constitucional, que establece la Ley Orgánica del Ministerio Público, contenido en el Boletín N².152 - 07, evacuado el 21 de julio de 1999.

${ }^{45}$ PIEDRABUENA RICHARD Guillermo: Introducción a la Reforma Procesal Penal (Santiago, Ed. Fallos del Mes, 2000) $100-101$
} 
puede menos que concebirse la aplicación del precepto contenido en el artículo $19^{\circ} \mathrm{N}^{\circ}$ $7^{\circ}$ letra i) tanto a las actuaciones del Tribunal cuanto a las del Ministerio Público.

La jurisdicción sigue siendo, por cierto, una sola y la misma, aunque las atribuciones que ella implica, en el ámbito penal, sean separadas por el Legislador:

"En fin, adviértase que, conforme a la Ley de Reforma Constitucional N 19.519 , se ha precisado que tanto el proceso cuanto la investigación deben ser racionales y justos, con motivo de que esta última, en el proceso penal, corresponderá al Ministerio Público y no al juez de la causa. Con todo y atendido que, como ya fue explicado, el proceso se aplica a todo órgano que ejerza jurisdicción, lo haga en plenitud o sólo respecto de alguna de sus fases, entonces, la precisión incorporada por la reforma resulta, de alguna manera, innecesaria" ${ }^{46}$.

Por cierto, la sentencia condenatoria, el sobreseimiento definitivo y la absolución son actos que sólo pueden ser adoptados por los Tribunales. Empero y al mismo tiempo, la estructura doble del Procedimiento Penal Nuevo, desde el punto de vista de la distribución de competencias entre el Ministerio Público y el Tribunal, no obsta a que aquél pueda realizar actuaciones que, siendo injustificadamente erróneas o arbitrarias, causen perjuicio al afectado que fue sometido a proceso, en los términos amplios con que dicha expresión tiene que ser entendida, según se ha explicado latamente ${ }^{47}, \mathrm{v}$. gr., al calificar la aplicación del Principio de Oportunidad, conforme al artículo $170^{\circ}$ del Nuevo Código de Procedimiento Penal; al resolver acerca de la autodenuncia, contemplada en su artículo $179^{\circ}$; al disponer la práctica de las diligencias contempladas en el artículo $181^{\circ}$, especialmente, las de su inciso $2^{\circ}$; o las que establece el artículo $197^{\circ} ; \mathrm{y}$, superlativamente, al formalizar la acusación, regulada en el artículo $259^{\circ}$.

En consecuencia, cuando concurran los requisitos establecidos en el artículo $19^{\circ}$ $N^{\circ} 7^{\circ}$ letra i) de la Constitución, cualquiera sea el autor del daño -el Ministerio Público o el Tribunal-, el afectado podrá acudir a la acción contemplada en aquel precepto fundamental. Empero, si alguno de los requisitos allí contemplados no se produce, entonces, el perjudicado, si se trata de una actuación u omisión del Ministerio Público, deberá acudir a la acción que le franquea el artículo $5^{\circ}$ de la Ley $N^{\circ} 19.640$; en cambio, si el agente causante es el Tribunal, deberá acudir a las acciones indemnizatorias comunes.

\footnotetext{
${ }^{46}$ FERNÁNDEZ GONZÁLEZ Miguel Angel citado en supra nota 37, p. 773. Léase, CEA EGAÑA José Luis citado en supra nota 27, p 21; e VARGAS DELGADO Iris: " La garantía del Justo y Racional Procedimiento en la Jurisdicción Tributaria " en XXV Revista Chilena de Derecho N³, pp. 549 - 552.

${ }^{47}$ El artículo $166^{\circ}$ inciso $2^{\circ}$ del Nuevo Código de Procedimiento Penal señala que el Ministerio Público promoverá la persecución penal. Dable es sostener, entonces, que, en los términos explicados, cabe asimilar el sometido a proceso a quien es sujeto de dicha persecución penal en calidad, al menos, de imputado
} 


\section{CONCLUSIONES}

El artículo $19^{\circ}^{\circ}=7^{\circ}$ asegura a todas las personas la libertad personal y seguridad individual, incluyéndose, en su letra i), el derecho a reclamar una indemnización del Estado cuando el afectado haya sido objeto de un error judicial, siempre que éste se haya producido en causa criminal, que el afectado haya sido sometido a proceso o condenado, en cualquier instancia; que se haya dictado a su respecto sobreseimiento definitivo o sentencia absolutoria; y que la Corte Suprema declare injustificadamente erróneo o arbitrario el sometimiento a proceso o la condena.

En relación con la expresión sometido a proceso, la Corte Suprema la ha considerado sinónimo del auto de procesamiento, restringiendo su alcance a la resolución referida en el artículo $274^{\circ}$ del Antiguo Código de Procedimiento Penal. Empero, dicha interpretación no es consistente con la historia y el espíritu de la norma referida, siendo necesario revisarla, con el objeto de dotarla de completa y extensiva aplicación, de forma tal que se la conciba en términos que se amparen, efectivamente, los derechos del afectado y su integridad moral y patrimonial. Lo anterior, especialmente considerando que, en el Nuevo Código de Procedimiento Penal, aquella resolución desaparece.

Por ello y conforme a los Principios de Supremacía Constitucional, Fuerza Normativa y Responsabilidad, todos valores del máximo nivel en nuestro Ordenamiento Jurídico, así como por lo asegurado en tratados internacionales que tienen jerarquía constitucional y por la constante evolución en la tutela de los derechos fundamentales, la expresión sometida a proceso tiene que ser interpretada en sentido amplio, esto es, que el afectado haya sido sujeto a un proceso penal, o sea, que a su respecto, cualesquiera sean las resoluciones que lo hayan afectado, se haya desarrollado, total o parcialmente, un proceso penal, sea que la actuación provenga del Ministerio Público o de los Tribunales, en forma injustificadamente errónea o arbitraria. En términos del Nuevo Código, que se haya promovido a su respecto al persecución penal.

En consecuencia, cuando concurran los requisitos establecidos en el artículo $19^{\circ}$ $N^{\circ} 7^{\circ}$ letra i) de la Constitución, cualquiera sea el autor del daño-el Ministerio Público o el Tribunal-, el afectado podrá acudir a la acción contemplada en aquel precepto fundamental. Empero, si alguno de los requisitos allí contemplados no se produce, entonces, el perjudicado, si se trata de una actuación u omisión del Ministerio Público, deberá acudir a la acción que le franquea el artículo $5^{\circ}$ de la Ley $N^{\circ} 19.640$; en cambio, si el agente causante es el Tribunal, deberá acudir a las acciones indemnizatorias comunes.

En fin y respecto del significado de las expresiones injustificadamente errónea o arbitraria, la Corte Suprema ha sido exigente para hacer lugar a la acción 
constitucional deducida por el afectado, en circunstancias que lo injustificadamente erróneo es la decisión, actuación o conducta que no puede justificarse o sustentarse en el expediente y que, por ende, constituye un error, pues, tratándose de un procedimiento judicial, su fundamento o explicación no se encuentra en los hechos o en el Derecho que consta en el expediente. A su turno, la arbitrariedad debe ser entendida conforme al concepto general con que ella ha sido empleada por el Poder Constituyente a lo largo de todo el Código Político. En este sentido, haber sometido a proceso o condenado a una persona será arbitrario, cuando el obrar del juez carezca de motivación, sustento, lógica o razonabilidad, obedeciendo nada más que al capricho o la inquina. 